\title{
Effect of Various Culture Parameters on the Bio-surfactant Production from Bacterial Isolates
}

\section{Arpita Roy*}

Department of Biotechnology, Delhi Technological University, New Delhi, India

\begin{abstract}
Biosurfactants are those compounds which contains both hydrophilic and hydrophobic moieties i.e., amphiphilic in nature. They have advantages over the chemical surfactant such as low toxicity, eco-friendly, etc. They possess wide range of industrial applications such as bioremediation, food processing, oil industries and health care. Various microorganisms have the ability to produce the potential biosurfactant. In the present study, microbial culture which showed highest biosurfactant activity i.e., SA3 based on the oil displacement activity and emulsion layer was selected for various culture parameters optimization. Sodium nitrate as a nitrogen source and dextrose as a carbon gives the highest biomass and biosurfactant production. Further $2 \%$ of dextrose and $2 \%$ of inoculum size provides the highest biomass and biosurfactant production. Growth kinetics and biosurfactant kinetics study reveals that the maximum biomass was produced after $96 \mathrm{~h}$ and maximum production of biosurfactant was after $72 \mathrm{~h}$ of incubation period. Overall, the results indicated the potential use of SA3 isolate in bioremediation processes.
\end{abstract}

Keywords: Biosurfactant; Carbon source; Nitrogen source; Inoculum size; Growth kinetics

\section{Introduction}

Consumption of petroleum is increasing rapidly in the industry due to this large amount of hydrocarbons are discharged into the environment, either deliberately or accidentally. In addition to this many small spills occur during the oil transport, recovery and refining [1]. Hydrocarbon contaminated soil causes severe damage to the local system as these pollutants accumulated in animals and plant tissue which lead to death [2]. Now-a-days there is an increased demand for innovative and environmentally friendly techniques to deals with these problems. A wide range of microbes has reported showing potential biosurfactant activity; these microbes have the ability to break down the organic compounds which they used as energy sources. Utilization of bio-compounds has emerged as a promising method to enhance and improve the effectiveness of bioremediation processes [3]. Biosurfactants are amphiphilic compounds which have the ability to reduce surface and interfacial tension of the surface. Biosurfactant can have several structures i.e., glycolipids, polysaccharide-lipid composite, phospholipid, mycolic acid, lipopeptide, lipoprotein, or the microbial cell surface itself [4]. Due to unique properties and a vast array of application, identification of new biosurfactant producing microbes are in great demand. Biosurfactants have various advantages they can be used as dispersing agents, moistening agents, emulsifiers, pharmaceuticals and cosmetics, mining, petroleum, beverages, and foods, etc [5]. In spite of these advantages, the low yield of biosurfactant is a major problem influencing its commercialization. The type and quantity of biosurfactants produced also depends on various factors like nitrogen and carbon source, temperature, aeration and trace elements also affect their production [6]. By considering the importance of biosurfactants and their potential role in biodegradation of hydrocarbons the present study was conducted to optimize the various culture parameters for the production of biosurfactant as well as the growth of the isolated culture.

\section{Material and Methods}

\section{Sample collection and isolation}

$10 \mathrm{~g}$ of petroleum contaminated soil sample was collected and placed into sterile zip lock bag and stored at $4^{\circ} \mathrm{C}$ immediately after they bought to the laboratory. Microbial cultures were isolated using Minimal salt medium (MSM). MSM contain (for 1L) $0.9 \mathrm{~g}$ of $\mathrm{Na}_{2} \mathrm{HPO}_{4}$ $0.7 \mathrm{~g}$ of $\mathrm{K}_{2} \mathrm{HPO}_{4}, 2.0 \mathrm{~g}$ of $\mathrm{NaNO}_{3}, 0.4 \mathrm{~g} \mathrm{MgSO}_{4} .7 \mathrm{H}_{2} \mathrm{O}, 0.1 \mathrm{~g}$ of $\mathrm{CaCl}_{2}$, $20 \mathrm{~g}$ of glucose and $2 \mathrm{~g} / \mathrm{l}$ of Trace salt $\left(\mathrm{FeSO}_{4}\right.$ and $\left.\mathrm{MnSO}_{4}\right)$. $\mathrm{pH}$ of the medium was adjusted to 7.2 by using $1 \mathrm{~N} \mathrm{NaOH}$ and autoclaved at $121^{\circ} \mathrm{C}$ and 15 psi pressure for 20 minutes. Bacteria were isolated and stored at $4^{\circ} \mathrm{C}$ for further use. From the ten bacterial cultures isolates the best biosurfactant producing isolate was chosen for optimization of various culture parameters i.e., SA3.

\section{Effect of different nitrogen source on the production of biosurfactant}

The choice of nitrogen source affects the biosurfactant production. In order to obtain higher biosurfactant activity, it is necessary to have proper combination of macro-nutrients in media. MSM containing six different nitrogen sources i.e., sodium nitrate, yeast extract, beef extract, peptone, ammonium chloride and ammonium sulphate were used for biosurfactant production and biomass production. All the cultures were incubated at $37^{\circ} \mathrm{C}$ for $72 \mathrm{~h}$.

\section{Effect of different carbon source on the biosurfactant production}

Five different carbon sources i.e., dextrose, galactose, sucrose, fructose and xylose were used for biosurfactant production. In shakeflask experiments, MSM containing different carbon source were tested to observe the effect on biomass and biosurfactant production. All the cultures were incubated at $37^{\circ} \mathrm{C}$ for $72 \mathrm{~h}$.

"Corresponding author: Arpita Roy, Department of Biotechnology, Delh Technological University, New Delhi-110042, India, Tel: (+98)-71-32424127; E-mail: arbt2014@gmail.com

Received October 12, 2017; Accepted December 15, 2017; Published December 22, 2017

Citation: Roy A (2017) Effect of Various Culture Parameters on the Biosurfactant Production from Bacterial Isolates. J Pet Environ Biotechnol 8: 350 doi: 10.4172/2157-7463.1000350

Copyright: (c) 2017 Roy A. This is an open-access article distributed under the terms of the Creative Commons Attribution License, which permits unrestricted use, distribution, and reproduction in any medium, provided the original author and source are credited. 


\section{Effect of different carbon concentration on the biosurfactant production}

The biosurfactant production was found to be dependent on the composition of the medium. In shake-flask experiments, three different percentage of carbon source i.e., dextrose (1\%, $2 \%$ and $5 \%)$ were used in MSM medium to observe the effect on biomass and biosurfactant production. All the cultures were incubated at $37^{\circ} \mathrm{C}$ for $72 \mathrm{~h}$.

\section{Effect of different size of inoculum on the biosurfactant production}

MSM medium containing three different concentration of inoculum size (1\%, $2 \%$ and $3 \%)$ were used in medium for the biomass and biosurfactant production. All the cultures were incubated at $37^{\circ} \mathrm{C}$ for $72 \mathrm{~h}$ and wet biomass was recorded.

\section{Screening methods for biosurfactant activity}

All the samples were tested for their biosurfactant production by using two methods.

Oil spreading assay: Oil spreading assay was developed by Morikawa [7]. $50 \mathrm{ml}$ of distilled water was added to the petri plate and the $20 \mu \mathrm{l}$ of diesel was added in to this petri plate to form a thin layer of oil. After this $10 \mu \mathrm{l}$ of culture supernatant was placed gently on the centre of the oil layer. Displacement of oil layer by formatting a clear zone indicates the biosurfactant presence. Formation of oil displacement was visualized under visible light and measured after 30 seconds, this correlates to the biosurfactant activity of isolates.

Emulsification assay: Emulsification assay was developed by Cooper and Goldenberg [8]. $2 \mathrm{ml}$ of diesel was taken in a test tube in which $1 \mathrm{ml}$ of culture supernatant was added and vortexed for 2 minutes for homogenous mixing. Emulsification activity was observed after $24 \mathrm{~h}$ and calculated by using the formula:

$$
\mathrm{E}_{24}=h_{\text {emulsion }} / h_{\text {total }} \times 100
$$

\section{Biosurfactant production and bacterial growth kinetics}

Production and growth kinetics study was conducted for the 168 h. The study was done in $250 \mathrm{ml}$ flask using $25 \mathrm{ml}$ of mineral salt media containing $2 \%$ dextrose as carbon source, sodium nitrate as a nitrogen source and $2 \%$ inoculum size. The cultures were incubated in orbital shaker at $37^{\circ} \mathrm{C}$ temperature for $168 \mathrm{~h}$ and readings were taken at regular interval of $24 \mathrm{~h}$.

\section{Results and Discussion}

This study revealed the effect of various culture parameters on biosurfactant production. Previously isolation of a new biosurfactant producing microbes was carried out in samples collected from petroleum contaminated soil. Ten morphologically distinct microbial colonies were screened for their potential activity. Out of these ten isolated bacteria, SA3 was chosen which has shown maximum oil displacement activity and emulsifying activity for further studies. Oil displacement method are indicative of surface wetting activity and emulsion assay is one of the criteria to support the selection of potential biosurfactant producers [5]. More than one screening method should be used for the primary screening to identify the potential biosurfactant producers [9].

Different culture parameters like nitrogen source, carbon source, the concentration of carbon source, initial inoculum size of the bacterial culture, etc effects the production of biosurfactant. The role of different nitrogen sources on biosurfactant production was observed (Table 1) and found that maximum production of biosurfactant was observed in the MSM medium containing sodium nitrate followed by MSM medium containing ammonium sulphate. This result was in agreement with Abdel-Mawgoud [10] who reported that most elevated production of biosurfactant utilizing ammonium nitrate and sodium nitrate as nitrogen sources. Wu [11] reported that nitrogen sources play a vital role in the production of biosurfactant. It was reported that Urea and $\mathrm{NaNO}_{3}$ were most efficient nitrogen source for bacterial isolates [5]. Ghribi and Ellouze-Chaabouni [12] reported the role of urea as a nitrogen source in biosurfactant production. Makkar and Cameotra [13] reported that some Bacillus isolates were not able to utilize the ammonium sulfate for biosurfactant or biomass production; however, they were able to utilize ammonium nitrate, sodium nitrate, or potassium nitrate.

Effect of various carbon sources in the biosurfactant production was also done (Table 2). It was observed that the medium containing dextrose as a carbon source was only able to produce biosurfactant activity while in another carbon source like galactose, sucrose, fructose, and xylose there was no production but the growth was present. The concentration of dextrose was also an important parameter for biosurfactant production (Table 3 ) and it was found out of $1 \%, 2 \%$ and $5 \%, 2 \%$ of dextrose-containing medium gives maximum production and biomass of a $190.373 \mathrm{mg}$ (Wet weight). Cunha [14] reported the use of gasoline as a carbon source for the production of biosurfactant. Zhang [11] reported the ability of $P$. aeruginosa for the biosurfactant

\begin{tabular}{|c|c|c|c|c|c|c|c|}
\hline \multirow{2}{*}{$\begin{array}{l}\text { Nitrogen } \\
\text { source }\end{array}$} & \multicolumn{2}{|c|}{24 hours } & \multicolumn{2}{|c|}{48 hours } & \multicolumn{2}{|c|}{72 hours } & \multirow{2}{*}{$\begin{array}{l}\text { Wet weight } \\
\text { After } 72 \\
\text { hours (mg) }\end{array}$} \\
\hline & $\begin{array}{l}\text { OD } \\
\text { (cm) }\end{array}$ & $\mathrm{EL}(\mathrm{cm})$ & $\begin{array}{l}\text { OD } \\
\text { (cm) }\end{array}$ & $\mathrm{EL}(\mathrm{cm})$ & $\begin{array}{l}\text { OD } \\
\text { (cm) }\end{array}$ & $\begin{array}{c}\text { EL } \\
\text { (cm) }\end{array}$ & \\
\hline $\mathrm{NaNO}_{3}$ & 0.0 & 0.0 & 1.1 & $18.7 \%$ & 3.5 & $35 \%$ & 208.14 \\
\hline $\begin{array}{l}\text { Yeast } \\
\text { extract }\end{array}$ & 0.0 & 0.0 & 0.3 & $5.0 \%$ & 1.0 & $11.7 \%$ & 111.21 \\
\hline Beef extract & 0.0 & 0.0 & 0.5 & $11.7 \%$ & 0.4 & $17.6 \%$ & 78.52 \\
\hline Peptone & 0.0 & 0.0 & 0.6 & $11.7 \%$ & 1.5 & $17.6 \%$ & 219.97 \\
\hline$(\mathrm{NH} 4)_{2} \mathrm{SO}_{4}$ & 0.0 & 0.0 & 1.2 & $18.7 \%$ & 3.3 & $29 \%$ & 293.72 \\
\hline $\mathrm{NH}_{4} \mathrm{Cl}$ & 0.0 & 0.0 & 0.9 & $17.6 \%$ & 3.0 & $23 \%$ & 280.95 \\
\hline \multicolumn{8}{|c|}{ OD: Oil Displacement, EL: Emulsion Layer } \\
\hline
\end{tabular}

Table 1: Effect of various nitrogen source on the biosurfactant production

\begin{tabular}{|c|c|c|c|c|c|c|c|}
\hline \multirow{2}{*}{$\begin{array}{l}\text { Carbon } \\
\text { source }\end{array}$} & \multicolumn{2}{|c|}{24 hours } & \multicolumn{2}{|c|}{48 hours } & \multicolumn{2}{|c|}{72 hours } & \multirow{2}{*}{$\begin{array}{c}\text { Wet weight } \\
\text { After } 72 \\
\text { hours (mg) }\end{array}$} \\
\hline & $\begin{array}{l}\text { OD } \\
\text { (cm) }\end{array}$ & $\mathrm{EL}(\mathrm{cm})$ & $\begin{array}{l}\text { OD } \\
(\mathrm{cm})\end{array}$ & EL (cm) & $\begin{array}{l}\text { OD } \\
\text { (cm) }\end{array}$ & $\mathrm{EL}(\mathrm{cm})$ & \\
\hline Dextrose & 0.0 & 0.0 & 1.5 & $16.6 \%$ & 4.0 & $38 \%$ & 108.60 \\
\hline Galactose & 0.0 & 0.0 & 0.0 & 0.0 & 0.0 & 0.0 & 84.69 \\
\hline Fructose & 0.0 & 0.0 & 0.0 & 0.0 & 0.0 & 0.0 & 22.24 \\
\hline Sucrose & 0.0 & 0.0 & 0.0 & 0.0 & 0.0 & 0.0 & 161.99 \\
\hline Xylose & 0.0 & 0.0 & 0.0 & 0.0 & 0.0 & 0.0 & 89.86 \\
\hline
\end{tabular}

Table 2: Effect of various carbon sources on the biosurfactant production.

\begin{tabular}{|c|c|c|c|c|c|c|c|}
\hline \multirow{2}{*}{$\begin{array}{c}\text { Concentration } \\
\text { of dextrose }\end{array}$} & \multicolumn{2}{|c|}{$\mathbf{2 4}$ hours } & \multicolumn{2}{c|}{$\mathbf{4 8}$ hours } & \multicolumn{2}{c|}{$\mathbf{7 2}$ hours } & Wet weight \\
\cline { 2 - 7 } & $\begin{array}{c}\text { OD } \\
\mathbf{( c m )}\end{array}$ & EL (cm) & $\begin{array}{c}\text { OD } \\
\text { (cm) }\end{array}$ & $\begin{array}{c}\text { EL } \\
\text { (cm) }\end{array}$ & $\begin{array}{c}\text { OD } \\
\text { (cm) }\end{array}$ & $\begin{array}{c}\text { EL } \\
\text { After 72 }\end{array}$ & $\begin{array}{c}\text { (cm) } \\
\text { hours (mg) }\end{array}$ \\
\hline $1 \%$ & 0.0 & 0.0 & 3.0 & $38.2 \%$ & 2.7 & $20 \%$ & 200.687 \\
\hline $2 \%$ & 0.0 & 0.0 & 1.1 & $18.7 \%$ & 3.633 & $38 \%$ & 190.373 \\
\hline $5 \%$ & 0.0 & 0.0 & 0.0 & 0.0 & 0.767 & $10 \%$ & 158.737 \\
\hline
\end{tabular}

OD: Oil Displacement, EL: Emulsion Layer

Table 3: Effect of different carbon concentration on the production of biosurfactant. 
Citation: Roy A (2017) Effect of Various Culture Parameters on the Bio-surfactant Production from Bacterial Isolates. J Pet Environ Biotechnol 8: 350. doi: 10.4172/2157-7463.1000350

production in $30 \mathrm{~g} / \mathrm{L}$ glycerol. Fleurackers [15] demonstrated the use of waste frying oils for biosurfactants production in Candida bombicola ATCC 22214

Then the influence of the different size of inoculum on the biosurfactant production was studied (Table 4), and it was observed that biosurfactant was best produced at $2 \%$ of inoculum. Biosurfactant production kinetics showed that the maximum amount of biosurfactant produced after $72 \mathrm{~h}$ (Table 5 and Figure 1) i.e., oil displacement of 4.2 $\mathrm{cm}$ and maximum growth of bacterial culture was at $96 \mathrm{~h}$ i.e., OD-1.596 (Table 5 and Figure 2).

\begin{tabular}{|c|c|c|c|c|c|c|c|}
\hline \multirow{2}{*}{$\begin{array}{c}\text { Size of } \\
\text { inoculum }\end{array}$} & \multicolumn{2}{|c|}{24 hours } & \multicolumn{2}{|c|}{48 hours } & \multicolumn{2}{|c|}{72 hours } & \multirow{2}{*}{$\begin{array}{l}\text { Wet weight } \\
\text { After } 72 \\
\text { hours (mg) }\end{array}$} \\
\hline & $\begin{array}{l}\mathrm{OD} \\
(\mathrm{cm})\end{array}$ & $\mathrm{EL}(\mathrm{cm})$ & $\begin{array}{l}\mathrm{OD} \\
(\mathrm{cm})\end{array}$ & $\mathrm{EL}(\mathrm{cm})$ & $\begin{array}{l}\mathrm{OD} \\
(\mathrm{cm})\end{array}$ & $\begin{array}{c}\mathrm{EL} \\
\text { (cm) }\end{array}$ & \\
\hline $1 \%$ & 0.0 & 0.0 & 0.6 & $18.7 \%$ & 3.5 & $28 \%$ & 183.06 \\
\hline $2 \%$ & 0.0 & 0.0 & 1.1 & $18.7 \%$ & 3.6 & $38 \%$ & 190.373 \\
\hline $3 \%$ & 0.0 & 0.0 & 1.0 & $35.2 \%$ & 3.5 & $26 \%$ & 197.733 \\
\hline
\end{tabular}

OD: Oil Displacement, EL: Emulsion Layer

Table 4: Effect of different size of Inoculum on the production of biosurfactant.

\begin{tabular}{|c|c|c|}
\hline Time (in hours) & $\begin{array}{c}\text { Production Kinetics (Oil } \\
\text { displacement activity (in cm) }\end{array}$ & $\begin{array}{c}\text { Growth Kinetics } \\
\text { (OD) }\end{array}$ \\
\hline 0 & 0 & 0 \\
\hline 24 & 0 & 0.329 \\
\hline 48 & 1.5 & 1.364 \\
\hline 72 & 4.0 & 1.468 \\
\hline 96 & 3.8 & 1.596 \\
\hline 120 & 3.0 & 1.570 \\
\hline 144 & 2.4 & 1.557 \\
\hline 168 & 1.5 & 1.412 \\
\hline
\end{tabular}

Table 5: Biosurfactant production and bacterial growth kinetics.

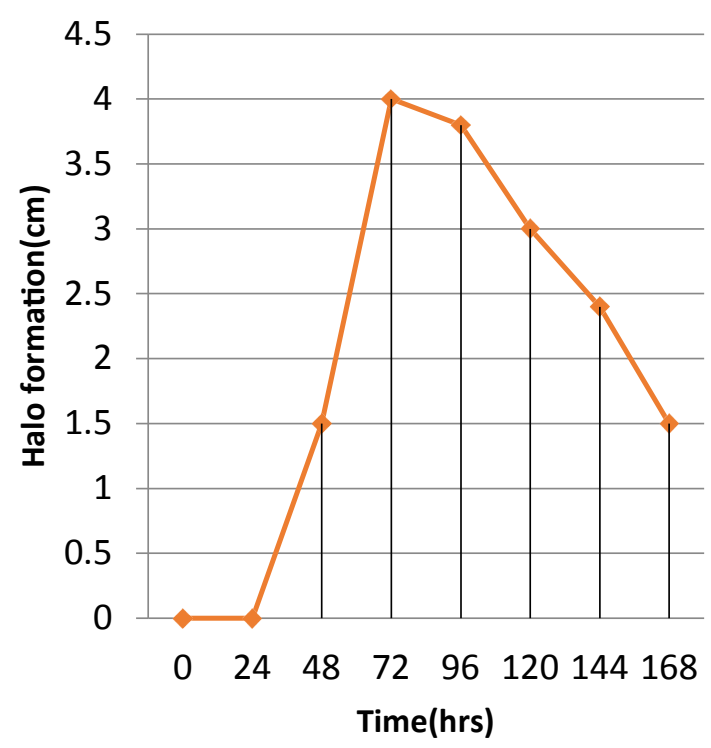

Figure 1: Production kinetics curve.

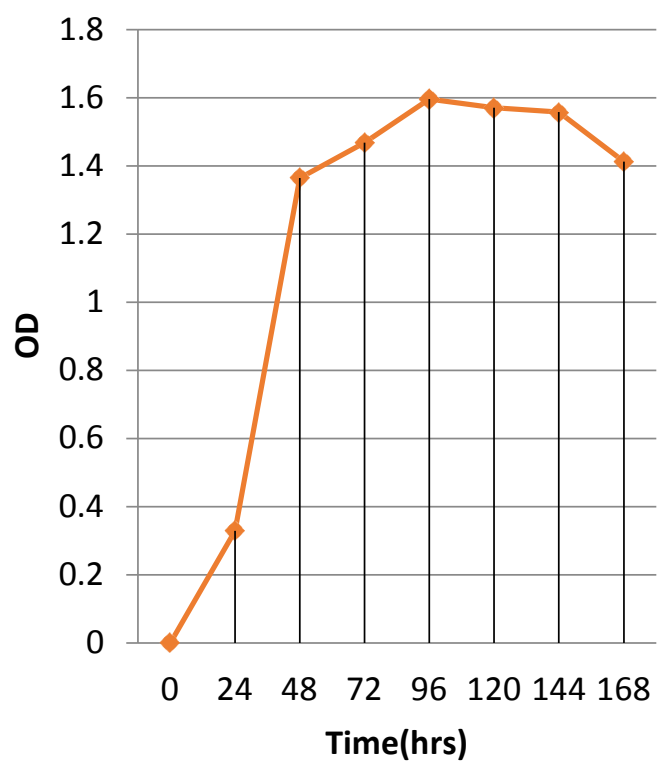

Figure 2: Growth kinetics curve.

\section{Conclusion}

The present study concludes that the culture parameters play vital role in the biosurfactant production as well as the biomass amount. It was observed that sodium nitrate, $2 \%$ dextrose and $2 \%$ inoculum size provides the best condition for the growth of the isolated bacterial culture and also the biosurfactant production. The culture is potential for production of biosurfactant and can be utilized further for larger production.

\section{Conflict of Interest}

The authors declare that there are no conflicts of interest.

\section{References}

1. Bolliger C (2000) Bioremediation of a heating oil-contaminated aquiferquantification of processes by chemical, biological and $\mathrm{s}$ isotope analyses.

2. Alvarez PJJ, Vogal TM (1991) Substrate interactions of benzene, toluene and oara-xylene during microbial deyredation by pure cultures and mixed culture quifer slurries. Applied and Environmental Microbiology 57: 2931-2985.

3. Ayed BH, Jemil N, Maalej H, Bayoudh A, Hmidet N, et al. (2015) Enhancement of solubilization and biodegradation of diesel oil by biosurfactant from Bacillus amyloliquefaciens AN6. Int Biodeter Biodegr 99: 8-14.

4. Ma Y, Oliveira RS, Freitas H, Zhang C (2016) Biochemical and molecular mechanisms of plant-microbe-metal interactions: Relevance for phytoremediation. Front Plant Sci 7: 918.

5. Elazzazy AM, Abdelmoneim TS, Almaghrabi OA (2015) Isolation and characterization of biosurfactant production under extreme environmental conditions by alkali-halo-thermophilic bacteria from Saudi Arabia. Saud Journal of Biological Sciences. 22: 466-475

6. Santos DKF, Rufino RD, Luna JM, Santos VA, Sarubbo LA (2016) Biosurfactants: Multifunctional Biomolecules of the $21^{\text {st }}$ Century. Taubert $A$ (ed.) Int J Mol Sci 17: 401.

7. Morikawa M, Hirata Y, Imanaka T (2000) A study on the structure-function relationship of lipopeptide biosurfactants. Biochim Biophys Acta 1488: 211-218.

8. Cooper D, Goldenberg B (1987) Surface-active agents from 2 Bacillus species. Appl Environ Microbiol. 53: 224-229.

9. Satpute SK, Bhawsar BD, Dhakephalkar, Chopade BA (2008) Assessment of different screening methods for selecting biosurfactant producing marine bacteria. Indian J Mar Sci 37: 243-250. 
Citation: Roy A (2017) Effect of Various Culture Parameters on the Bio-surfactant Production from Bacterial Isolates. J Pet Environ Biotechnol 8: 350. doi: 10.4172/2157-7463.1000350

Page 4 of 4

10. Abdel-Mawgoud AM, Aboulwafa MM, Hassouna NAH (2008) Optimization of surfactin production by Bacillus substilis BS5. Appl Biochem Biotechnol. 150: 305-325

11. Zhang G, Wu Y, Qian X, Meng Q (2005) Biodegradation of crude oil by Pseudomonas aeruginosa in the presence of rhamnolipids. J. Zhejiang Univ Sci B 6: 725-730.

12. Ghribi D, Ellouze-Chaabouni S (2011) Enhancement of Bacillus subtilis lipopeptide biosurfactants production through optimization of medium composition and adequate control of aeration. Biotechnol Res Int 1: 2
13. Makkar RS, Cameotra SS (1997) Biosurfactant production by a thermophilic Bacillus subtilis strain. J Ind Microbiol Biotechnol 18: 37-42.

14. Cunha CD, Do Rosário M, Rosado AS, Leite SGF (2004) Serratia sp. Svgg16 A promising biosurfactant producer isolated from tropical soil during growth with ethanol-blended gasoline. Process Biochem. 39: 2277-2282.

15. Fleurackers SJJ (2006) On the use of waste frying oil in the synthesis of sophorolipids. Eur J Lipid Sci Technol 108: 1-5. 